April 2007

\title{
Proliferation of Terminology and the Illusion of Progress
}

Payam Akhavan

Follow this and additional works at: https://digitalcommons.usf.edu/gsp

\section{Recommended Citation}

Akhavan, Payam (2007) "Proliferation of Terminology and the Illusion of Progress," Genocide Studies and Prevention: An International Journal: Vol. 2: Iss. 1: Article 9.

Available at: https://digitalcommons.usf.edu/gsp/vol2/iss1/9

This Articles is brought to you for free and open access by the Open Access Journals at Digital Commons @ University of South Florida. It has been accepted for inclusion in Genocide Studies and Prevention: An International Journal by an authorized editor of Digital Commons @ University of South Florida. For more information, please contact digitalcommons@usf.edu. 


\title{
Proliferation of Terminology and the Illusion of Progress
}

\author{
Payam Akhavan \\ Faculty of Law, McGill University; formerly Legal Advisor to the \\ Office of the Prosecutor, ICTY-ICTR, The Hague
}

As scholars and advocates, we are formidable taxonomists and explorers of distinctions, ever probing new conceptual frontiers in the elusive quest to render an overwhelming universe of human struggle more coherent and manageable. The proliferation of terminology, however, the incantation of new strategic mantras, while obviously relevant to the legal and political construction of the world, can often become a self-contained exercise creating the mere illusion of progress. In some circumstances, it can even divert precious resources away from the consolidation of existing, and hard-won, norms and institutions. In considering the introduction of the term "atrocity crimes" to the already complex lexicon of humanitarian discourse, we need to take account of its relative weight in terms of the most important challenges confronting the prevention of genocide. In particular, we need to ask whether the cost-benefit calculus of promoting this new concept and purported discipline justifies a significant commitment of energy and resources, whether intellectual or political, that might otherwise be focused on strengthening established concepts and disciplines that may be adequate but still at the margins of political consciousness. While I have the utmost respect and admiration for David Scheffer's unique contributions to the prevention and punishment of genocide and crimes against humanity, I have misgivings about the relative weight and importance that he assigns to "atrocity crimes" as a useful instrument for promoting this cause.

The argument that the loaded term "genocide" intimidates states from responding effectively must be assessed against the fact that alternative categorizations have only marginal impact on meaningful action where there is a failure of political will. Are we to conclude, for instance, that US willingness to characterize the Darfur situation as "genocide" resulted in a more robust response compared to Rwanda, where there was reluctance to use this term? Or, conversely, that if the term "atrocity crimes" had been used in an early-warning context, there would have been greater preventive engagement on the part of the United Nations prior to escalation into genocidal violence? Furthermore, the newly established mandate of the UN special adviser on the prevention of genocide clearly indicates that a prior legal determination that acts constitute genocide or crimes of comparable gravity is not required for preventive action. With the gradual mainstreaming of this mandate in the UN system, it is increasingly understood that there is a distinction between "genocide" and "prevention of genocide." In any event, to the extent that conceptual categorization has an appreciable impact in a preventive context, there is evidence that the elevated status of genocide or crimes of comparable gravity has justified prioritization of certain situations amidst the multitude of issues clamoring for global attention. A safer, more diluted concept such as "atrocity crimes" may actually undermine such privileged treatment. Even assuming that a less intimidating concept is required, 
there is no compelling reason not to use well-established and easily recognized terms such as "gross" or "large-scale" human-rights violations, which are standards applied in different contexts for prioritizing international scrutiny of certain situations by UN bodies. If anything, restricting "atrocity crimes" to the elementary category of war crimes while not including the broader category of human-rights violations falsely and dangerously assumes that abuses in situations not amounting to a state of war or armed conflict do not have the potential to culminate in genocide. It is also doubtful that a new concept of "atrocity crimes" would somehow focus the attention of the wider public and thereby mobilize opinion and encourage action. It is safe to assume that public calls for action are primarily the result of shocking contextualized images of suffering conveyed by the media, or the intimate accounts of survivors, and not of abstract legal categorization of situations. The bottom line is that what we need most is not a conceptual or rhetorical magic bullet but, rather, a greater focus on integrating and mainstreaming existing concepts and institutions into the daily habits and rituals of decision-makers, with a view to transforming an entrenched culture of reaction into a culture of prevention.

In certain respects, the preoccupation with preventive terminology emerged most forcefully in the crucible of Rwanda. It is well-known in genocide-studies circles that in 1994, during the extermination campaign against Tutsis, officials in the Clinton administration were instructed "not to describe the deaths as genocide, even though some senior officials believe that is exactly what they represent." ${ }^{1}$ There are some suggestions that this reluctance was based on the view that characterizing the killings as "genocide" would trigger application of the 1948 UN Convention on the Prevention and Punishment of the Crime of Genocide (UNCG) and the corresponding obligation under art. 1, whereby states parties "undertake to prevent and to punish" the crime of genocide. ${ }^{2}$ To the extent that denial of the term "genocide" was actuated by such a view, it is based on a false premise. In the Application of the Genocide Convention Case, the eminent judge ad hoc appointed by Bosnia-Herzegovina, Sir Elihu Lauterpacht, considered whether the duty to prevent under art. 1 "extends beyond the duty of each party to prevent genocide within its own territory to that of preventing genocide wherever it may occur."3 He surveyed contemporary incidents of genocide and concluded that "the limited reaction of the parties to the Genocide Convention in relation to these episodes may represent a practice suggesting the permissibility of inactivity." It is more significant that US officials were willing to admit that "acts of genocide may have occurred," because a label as stark as "genocide" would "inflame public calls for action the Administration is unwilling to take." In other words, it was the mere rhetorical force of genocide, its perception as the pinnacle of evil, that rendered its use controversial, rather than any particular legal consequences flowing therefrom. US Secretary of State Warren Christopher deflated the rhetorical onslaught of human-rights advocates by remarking dismissively that "if there's any particular magic in calling it a genocide, I have no hesitancy in saying that." ${ }^{6}$ During his visit to Kigali on 25 March 1998, a somewhat contrite President Bill Clinton said that the international community "bear[s] its share of responsibility for this tragedy....We did not act quickly enough after the killing began... we did not immediately call these crimes by their rightful name, genocide."7

A decade later, with the unfolding of "ethnic cleansing" in the Darfur region of Sudan, and conscious of the legacy of catastrophic moral failure in relation to Rwanda, US Secretary of State Colin Powell declared before the Senate Foreign Relations Committee that, based on evidence of "a consistent and widespread pattern of 
atrocities," he had concluded "that genocide has been committed in Darfur and that the Government of Sudan and the Jingaweit [sic] bear responsibility-and that genocide may still be occurring." 8 B October 2005, moreover, the UN World Summit "Outcome Document,"9 representing the largest-ever gathering of heads of state and government, had recognized the "responsibility to protect" populations, not only against genocide but also against war crimes, ethnic cleansing, and crimes against humanity. ${ }^{10}$ Despite the recognition of a collective responsibility on the part of the international community to intervene against genocide, and the willingness of the US government, at least, to characterize the situation as genocide, it is difficult to conclude that the international community's response to massive crimes in Darfur was significantly better than its response to events in Rwanda. Likewise, had the less offensive term "atrocity crimes" been deployed in a preventive capacity, it is doubtful that more effective action would be forthcoming. The impediment to an effective response was overwhelmingly a failure of political will, as in Rwanda a decade earlier, and the particular terminology adopted would have had a marginal impact at best. Use of the term "genocide" was hardly a "brake" on an effective response, because there was no effective response forthcoming in any event. It is in this light that we should assess the misguided exercise by the Security Council of establishing a commission of inquiry focused on whether or not the slaughter fulfilled the legal definition of genocide. The obvious issue simply was the prevention of genocide (or a similar crime of vast scale), not whether or not genocide had occurred. In this context, the commission's legal deliberations represented willful blindness on the part of the Security Council to the imperative of prevention. Against the backdrop of what was happening at the time, this legal hairsplitting was largely a pretense of useful activity, and the debate over the application of particular hierarchical abstractions a pretext for prolonging the ultimate decision not to take robust action against Sudan, not to protect the civilian population against subjection to obvious and outrageous horrors not in need of labeling. Had Secretary Powell insisted that "atrocity crimes" were being committed in Darfur, or had he perhaps claimed that "crimes against humanity" were being committed, there is little reason to believe that the reaction would have been any different. Surely, the urgency of acting in a preventive capacity against an enormous human catastrophe was not conceptually difficult for Security Council members to appreciate.

Perhaps the most significant development during the post-Rwanda period, a development with subtle but potentially far-reaching implications for transforming the capacity of the UN to act more effectively, is the recent establishment of a mandate on the prevention of genocide. On 12 July 2004, acting pursuant to art. 99 of the UN Charter and Security Council resolution 1366 of 2001, the secretary-general informed the Security Council of the appointment of Juan E. Méndez to serve as his special adviser on the prevention of genocide. ${ }^{11}$ The outline of the mandate, attached to a letter of the same date to the Security Council, provides in relevant part that the special adviser will

(a) collect existing information, in particular from within the United Nations system, on massive and serious violations of human rights and international humanitarian law of ethnic and racial origin that, if not prevented or halted, might lead to genocide; (b) act as a mechanism of early warning to the Secretary-General, and through him to the Security Council, by bringing to their attention potential situations that could result in genocide; (c) make recommendations to the Security Council, through the Secretary-General, on actions to prevent or halt genocide; (d) liaise with the United Nations system on activities for the prevention of genocide and work to enhance the United Nations capacity to analyse and manage information relating to genocide or related crimes. 
It is significant that this mandate is not much concerned with the definition of genocide. The terms of reference specifically indicate that "The Special Adviser would not make a determination on whether genocide within the meaning of the Convention had occurred. The purpose of his activities, rather, would be practical and intended to enable the United Nations to act in a timely fashion." ${ }^{12}$ A report on the work of the Office of the Special Adviser on Prevention of Genocide ${ }^{13}$ that I submitted on 7 November 2005, at the request of M. Mendez, reflects the views of a broad cross-section of actors within the UN system, including UN officials, member states, experts, and NGOs, on the prevention of genocide. These perspectives are particularly instructive for the present discussion on the strategic value of "atrocity crimes" as a single term that could help focus attention on prevention, at least within the UN system. The first observation is that the mandate relates to "genocide or related crimes" and is deliberately not restricted to a particular legal definition. The second is that "because the mandate of the Special Adviser is the prevention of genocide, it cannot be limited to situations that actually constitute genocide under the definition of that term in international law."14

With respect to the first point,

almost all respondents agreed that the Special Adviser's mandate should include any situation where identifiable groups were at risk of mass-killing or other forms of destruction. It was pointed out that the Secretary-General's speech before the 2004 session of the Human Rights Commission described the mandate as including "not only genocide but also [...] mass murder and other large-scale human rights violations, such as ethnic cleansing." This understanding is confirmed by the 2005 World Summit Outcome document which, in connection with the "responsibility to protect" populations from "genocide, war crimes, ethnic cleansing and crimes against humanity," endorsed the mandate of the Special Adviser. Several respondents pointed out that it would be inconceivable to exclude situations like the mass killing of political and social groups by the Khmer Rouge in Cambodia from the scope of the mandate. It was observed that in practice, it should be the quality and intention behind a potential attack against an identifiable group that guides the mandate rather than strict legal definitions. It was also remarked however, that an unduly broad interpretation of the type of situations that are relevant would dilute the narrow focus of the mandate and consequently, its added value within the United Nations system. ${ }^{15}$

Thus, there is a prevailing understanding within the UN system that the category of situations this mandate is intended to prevent includes atrocities broader than the crime of genocide, but that it should not be inordinately diluted either, since that would risk trivialization of the mandate, ultimately compromising its effectiveness as a focal point for action.

With respect to the second point, the report notes that

There is a conception of the Special Adviser's mandate that confuses prevention of genocide with intervention against genocide, and which thus looks to the Holocaust, Rwanda, or the Darfur, as the archetypal genocidal situations warranting the Special Adviser's attention. Early warning and prevention should not be understood in such an unduly narrow or stark sense. On some occasions, the Special Adviser's informal expressions of interest in a particular situation have been viewed with scepticism within the United Nations Secretariat on the basis that a conflict was merely political and did not contain an ethnic element, or that his assessment was alarmist and unnecessary. There is a need to defer to the Special Adviser's judgement in such situations since the potential for genocide may not always be apparent from a conflict prevention, human rights, or other perspectives. ${ }^{16}$ 
This addresses the most important and most misunderstood aspect of this mandate, and genocide prevention more generally-namely, that

the role of the Special Adviser should not be equated with an "alarm bell" warning of imminent genocide or mass murder. Early warning requires interaction and engagement within the United Nations system in order to improve the prospect of warnings leading to appropriate action in a timely fashion. For instance, instead of a public announcement of imminent atrocities, the Special Adviser could, at the early stages of a situation with genocidal potential, discretely inform the Security Council through the Secretary-General and propose the involvement of relevant actors such as donor States, international financial institutions, or non-governmental organizations. In other situations, the Special Adviser could make a discrete proposal to establish a fact-finding mission or initiate a good offices procedure. Such behind-the-scenes involvement, without any public reference to the mandate of preventing genocide, may ease the prospect of constructive engagement with the relevant government, where such an option exists. Early warning that leads to effective action must be seen as an organic process rather than a disjointed last-minute whistle-blowing exercise. ${ }^{17}$

If there is an urgent objective, it is the mainstreaming of this conception of prevention into an otherwise reactive culture within the UN system. Engagement of relevant actors is less a function of emphasizing the "genocide" label than of the daily habits and interactions within the decision-making process. As to the use of the term "genocide," my report once again is instructive in terms of the views of actors within the UN system:

A related issue, reinforcing the need for discrete networks of collaboration within the United Nations system, is the apparent stigma attached to the Special Adviser's mandate. There is a widespread perception that his interest or involvement in a given situation is an implicit indictment of a Government for the crime of genocide.... Such views disregard the express stipulation in the Special Adviser's mandate that he "not make a determination on whether genocide within the meaning of the [1948 Genocide] Convention ha[s] occurred."... Even supportive Member States view the title of the mandate as a liability given the unique stigma attached to the term "genocide." However, no convincing alternatives to the title have been proposed and some respondents have pointed out that it is both a liability and an asset, since the term "genocide" also imbues the Special Adviser with moral authority. Such considerations also point to an insufficient recognition of the discreet role that the Special Adviser can play in such situations without necessarily alerting Governments or the public to his direct involvement. ${ }^{18}$

Thus, in an early-warning context, the label of genocide is not so important, because the most effective response may typically be discreet engagement of influential actors rather than rallying public opinion. If circumstances are such that a more open and confrontational posture is required, then the genocide label may actually be an essential rhetorical weapon in galvanizing public opinion and calling for urgent attention to a particular situation. Again, however, it is doubtful whether introducing the new term "atrocity crimes" will make an appreciable difference rather than sowing more confusion by introducing new terminology into a decision-making context where it is a real struggle to integrate even established concepts in policy discourse.

Even if, in certain circumstances, there is a compelling need for a term that captures the early stages of a potentially genocidal situation, the mandate of the special adviser speaks to it in terms of "large-scale human rights violations," which, in effect, closely resembles the somewhat stricter concept of crimes against humanity. This is an important distinction from the concept of war crimes, which applies only to 
situations of armed conflict. War crimes, such as murder, torture, and rape, may be isolated or random acts; they are virtually identical with serious human-rights violations, except that in a state of armed conflict killing and injuring combatants is permissible. Thus, the right to life, liberty, and security of the person, as a peacetime human-rights standard, is more exacting than the lex specialis of international humanitarian law, which permits exceptions. Killings in peacetime would appear to be even more ominous than similar acts during an armed conflict, given the absolute protection of the right to life in such circumstances. In this respect, it is noteworthy that the contemporary definition of "crimes against humanity" in international law does not require a nexus with armed conflict, such that this broad category applies in peacetime as well. Although "large-scale human rights violations" can be substantially assimilated to this category in the broad context of humanitarian or policy discourse, crimes against humanity incorporate a legal requirement of a widespread or systematic attack against a civilian population, which may also become a pretext for futile or obstructive legal debate rather than effective preventive action. ${ }^{19}$ Perhaps this is why the secretary-general's definition of the mandate is deliberately broad and flexible in including the term "large-scale human rights violations." Thus, even if it were assumed that "atrocity crimes" is a useful label for prompting preventive action when a situation leading to potential genocide is still dormant, the concept should comprise not only war crimes but also large-scale violations of human rights. If anything, the worst genocides could occur in situations where one side is not in a position to offer military resistance, where there is no armed conflict but simply one-sided massacres, or where, at least, human-rights violations that are significant and ominous in a particular context, but not legally qualified as widespread or systematic, could quickly explode into large-scale violence. In Rwanda, large-scale though still limited human-rights violations-isolated massacres, for instance-and not war crimes preceded the onset of the genocide of April 1994; in Darfur, a low-intensity armed conflict with relatively few war crimes rapidly escalated to "ethnic cleansing" and genocide. So restricting "atrocity crimes" by not including violations of human rights is a potentially serious oversight. In any event, why reinvent the wheel when existing concepts are more than adequate? Even assuming that a less intimidating concept than "prevention of genocide" is required, there is no compelling reason not to use the well-established and easily recognized term "largescale human rights violations," as indicated in the UN mandate, or, alternatively, the similar term "gross" human rights violations, which was stipulated in UN Economic and Social Council Resolution 1503 (XLVIII) (1970) as the standard for situations requiring consideration by the UN Human Rights Commission. Why spend considerable time and effort to familiarize the UN system with a new concept, or to lobby for adoption of the standard in a resolution or internal guideline, when there is already a pressing need to internalize existing concepts? This is particularly so because the existing concepts are more than adequate for all the purposes that the proposed category of "atrocity crimes" is intended to serve.

It is also doubtful that the new term "atrocity crimes" would somehow focus the attention of the wider public. "Prevention of genocide" more clearly explains, in non-specialist terms, the reality of taking action in order to prevent something approximating mass killings or collective destruction. The term "prevention of atrocity crimes" would be inaccurate and misleading, since the only relevance in this context is that such crimes are a precursor to genocide or similar crimes. What we are really trying to say is that we should deal with "atrocity crimes" because they may lead to 
a much more serious crime, such as genocide. The phrase "prevention of genocide" more readily captures this concept among the uninitiated public. If any education is required, it is in the concept of "prevention" rather than that of "atrocity crimes." Ultimately, such atrocities are worthy of heightened attention because of the potential for genocide, and not all "atrocity crimes" necessarily imply escalation into mass killings or other forms of collective destruction that justify privileged treatment of such contexts.

We should also consider whether placing our faith in abstractions as a means of stimulating the will to act, especially among the wider public, overlooks the vital role of emotional connection with the stark horror of such situations, where rational normative schemes are certainly not at the forefront of people's minds. When we look at bodies littering the hills of Rwanda or the Darfur, is it the schematic labeling that arouses indignation and empathy, or the intimate face of suffering? Is our inordinate faith in intellectual concepts and terms not a privileging of distance over intimacy, a case of inadvertently placing abstractions over engagement? Is the more powerful form of cognition, in this context, not emotional rather than rational? Is it not the unspeakability of such evil, the ineffability of intense human suffering, that speaks most loudly to our conscience? The voices of survivors, the cruel reality of hatred and violence, are more potent than any term that we could devise in our rarefied midst as scholars and advocates.

When the UNCG was adopted on 9 December 1948, the president of the UN General Assembly triumphantly declared that "the supremacy of international law had been proclaimed and a significant advance had been made in the development of international criminal law." 20 The less euphoric prognosis of Sir Hartley Shawcross - the eminent British prosecutor at Nuremberg-was that, "while making no significant contribution to international law, the convention might ... delude people into thinking that some great step forward had been taken whereas in reality nothing at all had been changed." ${ }^{21}$ In retrospect, the culture of impunity that has prevailed for much of the UN era, and the continuing failure to intervene against genocide in places such as Rwanda and Darfur, gives some credence to Sir Hartley's skepticism about inordinate emphasis on legal definitions and proliferation of terminology. In considering whether "atrocity crimes" would make a substantial contribution to contemporary challenges, we should consider his admonition about creating the illusion of progress, and ponder whether our efforts would not be better placed in consolidating existing norms and concepts, painstakingly won and still at the margins of power.

\section{Notes}

1. Dougal Jehl, "Officials Told to Avoid Calling Rwanda Killings Genocide," New York Times, 10 June 1994, A8.

2. Convention on the Prevention and Punishment of the Crime of Genocide, 9 December 1948, 78 U.N.T.S. 277. See, e.g., Thomas W. Lippman, "Administration Sidesteps Genocide Label in Rwanda," Washington Post, 11 June 1994, A1.

3. Case Concerning Application of the Convention on the Prevention and Punishment of the Crime of Genocide (Bosnia and Herzegovina v. Serbia and Montenegro), separate opinion of Judge Lauterpacht, Order of 13 September 1993, International Court of Justice Reports 407, para. 113.

4. Ibid., para. 115 .

5. Jehl, "Officials Told," A8. 
6. See Philip Gourevitch, We Wish to Inform You That Tomorrow We Will Be Killed with Our Families: Stories from Rwanda (New York: Farrar, Straus \& Giroux, 1998), 153.

7. Cited in Linda Melvern, A People Betrayed: The Role of the West in Rwanda's Genocide (London: Zed Books, 2000), 230.

8. Colin L. Powell, "The Crisis in Darfur, Testimony before the Senate Foreign Relations Committee" (9 September 2004), http://www.usmission.ch/press2004/ 0910CrisisinDarfur.htm (accessed 2 January 2007).

9. Outcome Document of the 2005 World Summit, UN Doc. A/RES/60/1 (24 October 2005), http://www.un.org/summit2005/documents.html.

10. Ibid., paras. 138-39.

11. Outline of the Mandate for the Special Adviser on the Prevention of Genocide, UN Doc. S/2004/567 (13 July 2004), http://www.un.org/Depts/dpa/prev_genocide/appointment.pdf.

12. Ibid.

13. Payam Akhavan, "Report on the Work of the Office of the Special Adviser of the United Nations Secretary-General on the Prevention of Genocide," Human Rights Quarterly 28 (2006): 1043-70.

14. Ibid., 1059.

15. Ibid., 1060.

16. Ibid., 1052.

17. Ibid.

18. Ibid., 1053.

19. See, e.g., Rome Statute of the International Criminal Court, UN Doc. A/CONF.183/9 (17 July 1998), art. 7, reprinted in 37 I.L.M. 999 (1998).

20. UN GAOR, 3rd session, 179th plenary meeting, 852, UN Doc. A/PV.179 (1948).

21. UN Doc. GAOR, 3rd session, 6th Committee (1948), 17. 